\title{
ENHANCING STAKEHOLDER PARTICIPATION IN THE NIGER DELTA REGION: THE POTENTIAL CONTRIBUTIONS OF THE ILO CONVENTION 169
}

\author{
Afolasade A. Adewumi* \\ Adeniyi Olatunbosun**
}

\begin{abstract}
Tigeria's indigenous people, found in the Niger Delta area, have for 1 many years experienced developmental challenges associated with oil exploration. The region has been perennially engulfed in various forms of agitation pertaining to self-government and resource control. Over the years, attempts to solve these problems have been merely palliative, basically due to local stakeholders' perception that they are excluded from decision making about the issues that affect their existence. For many years, the Nigerian government has grappled unsuccessfully with the challenge of fostering broad-based participation and stakeholder engagement in the Niger Delta. This article contends that the problems which have arisen can be addressed through the ratification of the International Labour Organization (ILO) Convention 169 by the Nigerian government. Owing to a recent constitutional alteration in Nigeria, the ILO Convention 169 will not require domestication, arguably, making it a ready and viable toolkit for the progressive realization of participatory rights in the Niger Delta.
\end{abstract}

Keywords: Niger Delta, ILO, constitution, human rights, pollution, participation.

doi: http://dx.doi.org/10.4314/jsdlp.v6i1.6

* LL.B, LL.M, PhD, BL, Lecturer, Department of Jurisprudence and International Law, Faculty of Law, University of Ibadan, Ibadan, Nigeria.

* LL.B, LL.M, M.Phil, PhD, BL, Professor of Law and Dean, Faculty of Law, University of Ibadan, Ibadan, Nigeria. 


\section{INTRODUCTION}

$\mathrm{T}$ he International Labour Organization (ILO) Convention 169 on indigenous and tribal peoples was adopted in 1989 as an international treaty by the International Labour Conference of the International Labour Organization. ${ }^{1}$ The Convention aims at ensuring the protection of the rights of indigenous peoples by the governments of the nation states where they are found by including them in decision making that affect their existence. The Convention seeks to ensure that indigenous and tribal peoples are consulted and made to participate in defining their priorities for development while also recognizing their rights to land and natural resources which form the basis of their identity. Article 7(1) of the Convention succinctly puts it thus:

The peoples concerned shall have the right to decide their own priorities for the process of development as it affects their lives, beliefs, institutions and spiritual well-being and the lands they occupy or otherwise use, and to exercise control, to the extent possible, over their own economic, social and cultural development. ${ }^{2}$

This article seeks to explore how legal issues surrounding land disposition and resource control in the Niger Delta, which has, over the years, received many reactions from journalists, the public and learned authors yet without a concrete way forward, ${ }^{3}$ can be resolved through

1 See International Labour Organization, About ILO Convention 169 <http:// www.ilo.org/indigenous/Conventions/no169/lang-en/index.htm $>$ accessed 25 June, 2015.

2 ILO Convention 169 on indigenous and tribal peoples, 1989, Article 7(1).

3 For example: World Bank Report, "Defining an Environmental Development Strategy for the Niger Delta" (1995) Vols 1\& 2 81; Federal Government of Nigeria (2005) Niger Delta Regional Development Master Plan, Port Harcourt: NigerDelta Development Commission 25, A.I Pogoson, “The International Dimension of Reconciliation and Re-integration", in E.E Osaghae, R.T. Suberu \& E.E Osaghae, R.T. Suberu \& E. Onwudiwe (eds.) (2002) The Nigerian Civil War and Its Aftermath. (Ibadan: John Archers Ltd), pp. 207-215; S Muhammed "Reviewing Nigeria's Economic Interest and Development" <http://nigeriavillagesquare.com/ articles/guest-articles/reviewing-nigerias-economic-interest-anddevelopment.html> accessed 2 October 2015; “O. J. Offiong \& E. I. Okonmah, Internal Colonialism and Regional Resistance to Oil Exploitation in the Niger Delta" (2010) Journal of Research in National Development; "Internal Colonialism In The Niger-Delta?” The Tide Newspaper, <www.thetidenewsonline.com/2009/ 11/22/internal-colonialism-in-the-niger-delta/>accessed 2 October 2015; E.E Osaghae "Managing Multiple Minority 
Nigeria's ratification of the ILO Convention. The article is divided into six sections, the first being the introduction. The second section focuses on the Niger Delta people and how they qualify as indigenous people. The third section discusses the scope of land rights attributable to indigenous peoples under the Convention. The fourth section deals with the consultation and participation provisions of the Convention and how it will benefit the Niger Delta people. The fifth section is an analysis of the legal requirements for implementing the ILO Convention in Nigeria. The article concludes in section six.

\section{NIGER DELTA PEOPLE AND HOW THEY QUALIFY AS INDIGENOUS PEOPLE}

The United Nations (UN) has accepted the definition of indigenous peoples put forward by José Martínez-Cobo, the Special Rapporteur to the Sub-commission on the Prevention of Discrimination and Protection of Minorities. In his report, entitled Study of the Problem of Discrimination against Indigenous Populations, Cobo states:

Indigenous communities, peoples and nations are those which having a historical continuity with pre-invasion and pre-colonial societies that developed on their territories, consider themselves distinct from other sectors of societies now prevailing in those territories, or parts of them. They form at present non-dominant sectors of society and are determined to preserve, develop, and transmit to future generations their ancestral territories, and their ethnic identity, as the basis of their continued existence as peoples, in accordance with their own cultural patterns, social institutions and legal systems. ${ }^{4}$

In addition, the definition or "coverage" used in Article 1 of the International Labour Organization (ILO) Convention 169, is also widely accepted:

Problems in a Divided Society: The Nigerian Experience"; A.E Paki \& G.S Edoumiekumo "Colonialism and Political Conflict in Contemporary Nigeria: The case of the Niger Delta", June 2011 Vol. 1 No. 6 International Journal of Humanities and Social Science 276.

4 M.A. Bengwayan, Intellectual and Cultural Property Rights of Indigenous and Tribal Peoples in Asia, Minority Rights Group Report, May 2003. 
a. tribal peoples in independent countries whose social, cultural and economic conditions distinguish them from other sections of the national community, and whose status is regulated wholly or partially by their own customs or traditions or by special laws or regulations;

b. peoples in independent countries who are regarded as indigenous on account of their descent from the populations which inhabited the country, or a geographical region to which the country belongs, at the time of conquest or colonization or the establishment of present state boundaries and who, irrespective of their legal status, retain some or all of their own social, economic, cultural and political institutions. ${ }^{5}$

Moreover, and most importantly, in accordance with indigenous peoples' perspectives, both definitions emphasize self-identification as one of the main variables. It should be noted here that, despite common characteristics, no single accepted definition of indigenous peoples captures their diversity. Therefore, self-identification as indigenous or tribal is usually regarded as a fundamental criterion for determining indigenous or tribal groups, sometimes in combination with other variables such as language spoken and geographic location or concentration.

They are among the poorest of the poor, not only because of their economic marginalization but also because they are deprived of basic social, cultural and political rights and fundamental freedoms, including rights to their lands, territories and resources. Indigenous peoples inhabit lands rich in natural resources. Consequently, they are strongly affected by the operations of national and transnational companies. At the same time, indigenous peoples' exclusion from political decision-making processes - locally, nationally, regionally and globally - places them in a position of extreme disadvantage vis-à-vis imposed industrial activities that affect their individual and communal lives, territories and resources. This is particularly evident in the case of the extractive sector. ${ }^{6}$

5 International Labour Organization's (ILO) Convention 169, Article 1.

6 Indigenous peoples, transnational corporations and other business enterprises, IWGIA Briefing Note January 2012, <www.iwgia.org>accessed 1 October 2015.

7 IFAD (2007), Statistics and key facts about indigenous peoples $<$ www.ifad.org/ english/indigenous/> accessed 1 October 2015. 
Indigenous peoples constitute about one-third of the world's 900 million extremely poor rural people, ${ }^{7}$ and face huge disparities in access to, and in quality of, education and health. In Guatemala, for example, 53.5 per cent of young indigenous people aged 15-19 years have not completed primary education, compared to 32.2 per cent of nonindigenous youth. ${ }^{8}$ In Bolivia, the infant mortality rate among the indigenous populations is close to 75 of 1,000 , compared to 50 of 1,000 for the non-indigenous population. ${ }^{9}$

Innumerable studies, as well as indigenous peoples' testimonies, ${ }^{10}$ have documented serious human rights violations resulting from the activities of corporations on indigenous peoples' lands, including loss of, or damage to: indigenous lands, indigenous subsistence economies, and the health, language and cultural resources of indigenous communities. ${ }^{11}$ Research conducted by Prof. John Ruggie, the former UN Special Representative on Business and Human Rights, concluded that "the extractive sector oil, gas, and mining - utterly dominates this sample of reported abuses."12

Oil is one of the mineral resources found in land and it is one of the most powerful tools of trade in the world. The most powerful countries in the world, therefore, hold great control over this resource that is needed

8 UNESCO (2004) La conclusión universal de la educaciónprimaria en América Latina: estamosrealmente tan cerca? Informe Regional sobre los objetivos de desarrollo del Mileniovinculados a la educación.

9 ECLAC (2005), Millennium Development Goals: A Latin American and Caribbean Perspective <www.unicef.org/lac/spbarbados/.../UNECLAC_MDG_ 2005.pdf> accessed 1 October 2015.

10 ibid.

11 See, for example, International Work Group for Indigenous Affairs (2011). The Indigenous World 2011.Copenhagen: IWGIA <www.iwgia.org/iwgia.../ 0454_THE_INDIGENOUS_ORLD-2011_eb.pdf>accessed 1 October 2015.

12 Interim Report of the Special Representative of the Secretary-General on the Issue of Human Rights and Transnational Corporations and Other Business Enterprises, UN Doc. E/CN.4/2006/97; It is estimated that as much as $50 \%$ of the gold produced between $1995 \& 2015$ and up to $70 \%$ of copper production by 2020 will take place on the territories of Indigenous Peoples. See Moody, Roger The lure of gold: bow golden is the future? Panos briefing May, 1996, no. 19, Panos Institute; R Moody "Presentation to the Communities Confronting Mining" Corporations Seminar May 2001 London, England; in 2009, the European Commission noted that approximately $70 \%$ of the uranium used in nuclear reactors was sourced from the homelands of Indigenous Peo-ples worldwide. See Letter from Gundjeibmi Aboriginal Corporation to UN Secretary General April 2011. 
to run almost every sector right from the huge industries to simple generators in the home. Africa is one of the world's largest oil producers after the Middle East. ${ }^{13}$ Nigeria is Africa's largest oil producer with about 2.5 million barrels being produced a day. This makes her the fifth highest world exporter of oil. ${ }^{14}$

Nigeria's oil deposits are naturally endowed in the Niger Delta region, in the south-south geopolitical zone of the country. The extraction of oil which began in $1956^{15}$ has turned the nation to the leading oil producing/ exporting country in Africa. The exploitation of oil from 1956 to the present moment is being undertaken as a joint venture between multinational oil companies ${ }^{16}$ and the Federal Government of Nigeria. ${ }^{17}$

The proceeds of oil extraction have become the main source of Nigeria's annual foreign exchange earnings. ${ }^{18}$ With millions of barrels of oil harvested per day, and an over 90 per cent income to Nigeria, ${ }^{19}$ the Niger Delta provides economic strength to sustain the country. Yet, the Niger Delta remains undeveloped, with few or no infrastructure in health, schools, transportation, industries, federal and state government presence, etc. The people feel angered, realizing that the resources from their own

13 Top 10 Oil Producing Countries in Africa <www.gistmania.com/talk/topic, 150818.0.html> accessed 1 October 2015.

14 C. Davis, “Top 10 Oil Producing Countries in Africa 2015” $<w w w . r i c h e s t l i f e s t y l e . c o m / t o p-10$-oil-producing-countries-in-africa/10/> accessed 1 October 2015; M.L. Tuttle, M.E. Brownfield \& R.R. Charpentier “Tertiary Niger Delta (Akata-Agbada) Petroleum System(No. 701901), Niger Delta Province, Nigeria, Cameroon, and Equatorial Guinea, Africa" in The Niger Delta Petroleum System: Niger Delta Province, Nigeria, Cameroon, and Equatorial Guinea Africa <http://pubs.usgs.gov/of/1999/ofr-99-0050/OF9950H/OF99-50H.pdf $>$ accessed 2 October 2015.

15 A. Walker "The day oil was discovered in Nigeria” http://news.bbc.co.uk/1/hi/ world/africa/7840310.stm(accessed 1 October, 2015); oil exploration began in 1958 in Ogoniland. See Brief Historical Background of Ogoni, <http://giapf.org/ ogoni_history.htm>accessed 1 October 2015.

16 The multi-national companies are Shell, Chevron, Texaco, Elf and Agip.

17 A. Walker (n 14)

18 G.A. Okwandu, P.U. Agundu \& C.N. Achigbu "Multinational Companies and Joint Venture Investment Management Strategy: A Contemporary Diagnosis of Nigeria's Oil Sector" <www.jsd-africa.com/Jsda/Spring2005/ArticlePDF/ Arc_Multinational\%20Companies\%20and\%20Joint\%20Venture.pdf $>$ accessed 1 October 2015.

19 ibid. 
territory are being used to develop the Federal Capital Territory and places outside their territory, to finance bureaucracies and personalized, individualized conspicuous consumption, and official and non-official corruption. ${ }^{20}$

In relation to the Niger Delta people, environmental degradation has dealt a lethal blow on them. ${ }^{21}$ Political marginalization, oppression and genocide have characterized them. They have equally suffered from a denial of their rights, including land rights. They have demanded for autonomy and self-identification. They suffer several disabilities. Mining rents and royalties for Ogoni oil are not being paid to Ogoni people. ${ }^{22}$ In spite of the enormous wealth of the land the Ogoni people continue to live in pristine conditions in the absence of electricity, pipe-borne water, hospitals, housing and schools. ${ }^{23}$

As at date, the communities and the people of Niger Delta are no better off than they were in 1958. To the people of the Niger Delta who have, over the years, clamoured for a space in the Nigerian sun, resources do not exclusively mean only oil and gas, as much of the clamour for

20 See S.K Dato-Bash, "Rights of indigeneous people in relation to natural resources development - An African's perspective” (1998) vol.16, no.4 Journal of Energy and Natural Resources Law.

21 Mangrove forest has fallen to the toxicity of oil; the rain forest has fallen; all wildlife is dead; marine life is gone; farmland has been rendered infertile by acid rain. See generally Environmental Rights Action and The Climate Justice Programme "Gas Flaring in Nigeria: A Human Rights, Environmental and Economic Monstrosity” June 2005; O.T. Badejo \& P.C. Nwilo Management of Oil Spill Dispersal along the Nigerian Coastal Areas' (2004) J.Hum. Ecol., 16(3) 203-214; C.O. Orubu, A Odusola \& W. Ehwarieme 'The Nigerian Oil Industry: Environmental Diseconomies, Management Strategies and the Need for Community Involvement' (2004) J.Hum. Ecol., 16(3) 203-214; UNDP, Niger Delta Human Development Report 2006; E.I. Ohimain, T.O. Imoobe \& D.S. Bawo 'Changes in water physico-chemical properties following the dredging of an oil well access canal in the Niger-Delta (2008) World Journal of Agricultural Sciences 4 (6) 752-758 ISSN 1817-3047; Amnesty International interview with Solomon Braide, Institute of Pollution Studies, Rivers State University of Science and Technology, Port Harcourt, March 2008; Dredge spoils are often poor in plant nutrients and rather acidic, thus while they do not support plant growth, they leach acidic content into the water bodies; E.I Ohimain A. Wim and E.F. Martinus van Mensvoort "Environmental impacts of abandoned dredged soils and sediments" March 2004 Journal of Soils and Sediments Springer, Berlin/ Heidelberg.

22 S.K. Dato-Bash (n 20)

23 The Tide Newspaper, 24 May, 2013<www.thetidenewsonline.com/2013/05/24/ niger-delta-and-resource-control/> 
corporate and governmental control tends to suggest. Resources mean primarily land for agriculture, waters for fishing, forests for collecting and air for living and the other physical and spiritual biota. Resource control is the term used to describe the desire and determination of the communities and people whose resources and or sources of survival have been taken away violently and undemocratically and therefore unjustly. It denotes the need to regain ownership, control, use and management of resources for the primary benefit of the communities and people on whose land the resources originate and for good governance and development of the entire country.

Faced by the terrible odds earlier mentioned, the Ogoni people have continued courageously to demand social justice and equality. ${ }^{24}$ In October 1990, chiefs and leaders of Ogoni submitted a Bill of Rights to the Nigerian president and his council. The Bill called (a) for political control of Ogoni affairs by the Ogoni people; (b) the right to control and use a fair proportion of Ogoni economic resources for Ogoni development; (c) adequate and direct representation as of right in all Nigerian national institutions; (d) use and development of Ogoni languages in Ogoni territory; and (e) the right to protect the Ogoni environment and ecology from further degradation. The Ogoni are yet to receive a reply to these minimum demands. ${ }^{25}$ Recently, ${ }^{26}$ one of the governors of the states in the Niger Delta, Emmanuel Uduaghan, stated that, as a nation, Nigeria should mobilize resources and have the political will to clean up the devastated environment of the Niger Delta which he views as a more important, though more ignored, aspect of resource control. The above facts qualify the Niger Delta people as indigenous people.

\section{THE SCOPE OF LAND RIGHTS ATTRIBUTABLE TO INDIGENOUS PEOPLES UNDER THE CONVENTION}

Indigenous peoples cannot achieve the determination of the right to determine their priorities for development outside their rights to land

24 S.K. Dato-Bash (n n20).

25 ibid; See a communiqué issue by the governors of the south- south zone of Nigeria at end of a meeting on the 4 November 2000 on resource control.

26 Etaghene A, "Niger Delta: Looking Beyond Resource Control", The Pointer Newspaper (Friday, Oct. 2 2015). <http://thepointernewsonline.com/?p=10568> 
and natural resources. The recognition of the spiritual and cultural values attached to land by indigenous peoples is germane to the ILO Convention 169. The land rights are hinged on traditional occupation and use, which they intend to pass to their future generations whether or not the State recognizes it. ${ }^{27}$ Under the Convention, ${ }^{28}$ the national governments are to ensure that mechanisms are in place to identify and protect ownership and possession rights of indigenous peoples, as well as how to resolve land disputes. ${ }^{29}$ Mechanisms abound in the Convention to prevent the displacement of the people from their land except in exceptionally unavoidable situations, which must be with their free and informed consent. $^{30}$

In circumstances where their consent cannot be obtained, appropriate procedures laid down by national laws, regulation and public inquiries, which provide for effective representation of the people must be followed. ${ }^{31}$ Once grounds for relocation cease to exist, the people have the right to return to their traditional lands, ${ }^{32}$ the impossibility of which entitles them to be settled in lands of equal quality and legal status to that previously occupied by them. If they desire compensation in cash or kind as opposed to relocation, their request should be granted under appropriate guarantees. ${ }^{33}$

As regards their right to natural resources on their land, Article 15 is clear. The Article states that their rights in this regard will be specially safeguarded and in situations where the State retains ownership of mineral or sub-surface resources like Nigeria, ${ }^{34}$ government should put mechanisms in place to consult the people and ascertain whether and to what degree their interests would be prejudiced. They will also participate in the benefits and receive fair compensation. ${ }^{35}$

27 Committee of Experts on the Application of Conventions and Recommendations, 73rd Session, 2002, observation, Peru, para. 7.

28 ILO Convention 169, Articles 13-16.

29 ILO Convention 169, Article 14.

30 ILO Convention 169, Article 16.

31 ILO Convention 169, Article16(2).

32 ILO Convention 169, Article 16(3).

33 ILO Convention 169, Article 16(4).

34 Constitution of the Federal Republic of Nigeria, 1999 Cap. C 23, Laws of the Federation of Nigeria (LFN) 2004 (1999 Constitution) Section 44(3); Petroleum Act 1969, Cap. P10, LFN 2004, Section 1; Attorney-General of the Federation $v$. Attorney-General of Abia State and 35 others (2001)7 SCNJ 1; AG Federation v. AG Abia State and 35 Ors. (NO2) (2002) 4 SCNJ 1.

35 ILO Convention 169, Article 15(1)\&(2). 
In ensuring the compliance with the above provisions, the Committee of Experts on the Application of Conventions and Recommendations cannot however make recommendations on the suspension of activities pending consultation, not being armed with the powers of a court to grant injunctions or provisional measures. Therefore, to resolve disputes between the indigenous communities and the private sector actors who have licences to operate, the State should ensure that the correct application of the right to participation and consultation is well taken care of for implementing the Convention. This will create the platform for indigenous people to obtain redress in the law courts.

\section{THE CONSULTATION AND PARTICIPATION PROVISIONS OF THE CONVENTION AND HOW IT WILL BENEFIT THE NIGER DELTA PEOPLE}

Any democratic government that makes room for inclusive development would fundamentally have consultation and participation as part of the principles in achieving its objectives, and Nigeria should not be an exception. Consultation is a very important element in ensuring equity and guaranteeing social peace through inclusion and dialogue. It is also very instrumental in the prevention and resolution of conflict generated by the increasing exploitation of natural resources under the territory traditionally occupied by indigenous population. ${ }^{36}$

The Convention lays down a general obligation to consult with the indigenous people whenever any administrative or legislative measures affect them directly such as construction of roads, exploration or exploitation of sub-surface resources ${ }^{37}$ and before relocation or land alienation. ${ }^{38}$ The collective nature of the rights of indigenous peoples and the need to safeguard their cultures and livelihoods are reasons for the adoption by governments of special measures for their consultation and participation in decision making. ${ }^{39}$ The consultation must be done through their representative institutions, in good faith, and in line with appropriate

36 CEACR, General Observation on Convention No. 169, 79th Session, 2008, published 2009.

37 ILO Convention 169, Article 15(2).

38 ILO Convention 169, Article 17.

39 Handbook for ILO Tripartite Constituents. Understanding the Indigenous and Tribal Peoples Convention, 1989 (No.169): International Labour Office, p. 13.

40 ILO Convention 169, Article 6(2). 
procedures with the objective of achieving agreement or consent to the proposed measures. ${ }^{40}$ Consultation should also be done if special vocational training programmes are being organized and carried out for them; ${ }^{41}$ and also when undertaking literacy and educational programmes and measures beneficial to them. ${ }^{42}$ To effectively achieve the Convention's obligations as regards consultation, States must have institutional mechanisms for regular and broad consultation as well as specific mechanisms for specific communities. ${ }^{43}$ Pro forma consultation or mere information will not meet the Convention's requirements. ${ }^{44}$

The Committee views the obligation to consult as an issue that cannot be overemphasized because if the people are not carried along, the development programmes may not be successful because the projects do not reflect the aspirations and needs of the people. ${ }^{45}$ Consultation should however be carried out with the representative institutions that were established as a result of the process carried out by the indigenous peoples themselves; ${ }^{46}$ otherwise, the resulting consultations would not comply with the requirements of the Convention. ${ }^{47}$

Where the provisions of the Convention are not adequately implemented as regards consultation, it will lead to exclusion, conflicts and confrontations. The Convention states that governments should:

establish means by which these people can freely participate, to at least the same extent as other sectors of the population, at all levels of decision making in elective institutions and administrative and other bodies responsible for policies and programmes which concern them. ${ }^{48}$

The concept of participation also features in Article 7(1), which stipulates that indigenous peoples shall "participate in the formulation, implementation and evaluation of plans and programmes for national and regional development which may affect them directly." Article 33 requires governments to establish agencies or other appropriate mechanisms to ensure "the planning, coordination, execution and evaluation, in

41 ILO Convention 169, Article 22.

42 ILO Convention 169, Articles 27 and 28.

43 Handbook for ILO Tripartite Constituents, (n 38) p. 12.

44 CEACR General Observation, 2010, published 2011.

45 CEACR, General Observation on Convention No. 169, 2009 and 2011.

46 ILO Governing Body, 289th session, 2004, document GB.282/17/3.

47 ILO Governing Body, 282nd session, 2001, GB.282/14/2.

48 ILO Convention 169, Article 6(1). 
cooperation with the peoples concerned, of the measures provided for in this Convention."

In the body of the Convention phrases like, obligation to "cooperate" with indigenous peoples; obligation not to take measures contrary to the "freely expressed wishes" ${ }^{49}$ of indigenous peoples; and the obligation to seek "free and informed consent" ${ }^{50}$ of indigenous people where "relocation ... is considered necessary as an exceptional measure," ${ }^{51}$ depict the concept of participation. Consultation and participation are linked together, in that indigenous population must influence externally initiated proposals and also participate actively in activities that shape their development by creating initiatives, thereby forming their own priorities and exercising control over their economic, social and cultural development. ${ }^{52}$

\subsection{Harnessing Indigenous Peoples' Rights Within the Nigerian Political Milieu}

The political corruption, the deepening crisis of governance, and the escalating violence in and around "resource control" in the Niger Delta region should not be seen as secessionist, or as left insurgency. It is also not a provocation or prelude to massive civil war because one should not fail to see that these and other movements (some ethnic like the Ogoni political movement (MOSOP), some pan-ethnic like the Kaiama Declaration) had actively engaged in a debate about access to and control over resources within the federation, and by extension an engagement with the Nigerian Constitution and what it means to be a full citizen. The fact that massive poverty, disenfranchisement and a long dark history of military violence produced forms of politics that are neither civil nor democratic in the Niger Delta shouldn't be seen as being out of the

49 ILO Convention 169, Article 4(2).

50 ILO Convention 169, Article 16.

51 ILO Convention 169, Article 16(2).

52 ILO Convention 169, Article 7(1).

53 O. Douglas, V. Kemedi, I. Okonta, and M. Watts "Oil and Militancy in the Niger Delta: Terrorist threat or another Colombia?” (2004) Niger Delta Economies of Violence Working Papers Working Paper No 4; see generally J. Anderson "Blood and Oil" The New Yorker (14 August 2001) 46-59; V. Kemedi "Oil on troubled waters", Environmental Politics Working Papers (2002) Berkeley: Institute of International Studies, UC Berkeley <http: globetrotter.berkeley.edu> accessed 19 March 2015; M. Klare, Resource wars (2001); R. Vitalis “Black Gold, White Crude” (2002) Diplomatic History, 26/2 185-213. 
expected. ${ }^{53}$ Osaghie has summarized the situation in Niger Delta thus:

... the political conflict in the Niger Delta has pitched segments in the Niger Delta region, involving youth groups, women, elders, chiefs, and even governments of states in the region against the Nigerian state and its agents. This necessitated recurrent issues of debate leading to the need to unearth the root cause of conflict in order to properly understand it and appropriate solutions to be formulated and applied. ${ }^{54}$

At this juncture, it can be said that the cause of conflict, which Osaghie says needs unearthing, is the fact that the Niger Delta people are only agitating as indigenous people would. The solution needed is expressly spelt out in the ILO Convention 169. The people want to be consulted and to participate in decisions and programmes that affect their lives. Examples can be drawn from Guatemala in 1996 and Nepal in 2007 to the effect that Convention 169 was ratified as an integral element of peace accords to end civil wars rooted in exclusion of certain sectors of the population. ${ }^{55}$

Bearing in mind the fact that there exists agitation, confrontation, violence and exclusion, mistrust can be a key obstacle to achieving consultation carried out in good faith between the indigenous population of Niger Delta and the Nigerian government. Consultation may also not be carried out adequately due to the fact that this right is a new development. A way out of these has already been discovered by a Tripartite Committee of the Governing Body in the context of a particular country thus:

... the climate of confrontation, violence and lack of mutual trust stopped the consultations from being consulted more productively. It is imperative in all consultations to establish a climate of mutual trust, but all the more so with respect to indigenous peoples, given their lack of trust in state institutions and their feeling of marginalization, both of which have their origins in extremely old and complex historic events, and both of which yet have to be

54 E.E. Osaghae, "Managing Multiple Minority Problems in a Divided Society: The Nigerian Experience” (1998) The Journal of Modern African Studies, 36 1; A.E. Paki \& G.S. Edoumiekumo "Colonialism and Political Conflict in Contemporary Nigeria: The Case of the Niger Delta” (June 2011) International Journal of Humanities and Social Science Vol. 1 No. 6, 276.

55 Handbook for ILO Tripartite Constituents (n 38) 17.

56 Governing Body, 289th session, March 2004. Representation made under Article 24 of the ILO Constitution, Mexico, GB 289/17/3. 
overcome..$^{56}$

The solution is, therefore, for the government to create an atmosphere of mutual trust. Also, government should establish agencies or appropriate mechanisms with resources needed to carry out their functions and the effective participation of the indigenous people. The Convention did not strictly specify a particular model to be followed to ensure giving the people a real voice in the policies likely to affect them. ${ }^{57}$ Each country is allowed to implement the Convention in a unique way fashioned to its specific social, cultural, geographical, economic and historical circumstances thereby allowing for flexibility. The base line is that ministries responsible for mining or finance should not make decisions as regards indigenous people without any coordination with the agency responsible for their rights.

\section{LEGAL REQUIREMENTS FOR IMPLEMENTING THE ILO CONVENTION IN NIGERIA}

Section 12 of the 1999 Constitution no longer binds all labour related international conventions, treaties and protocols ratified in Nigeria. The amendment in Section 254(c) $(2)^{58}$ has brought about a change in the constitutional provision of section 12 , which makes it mandatory for any international treaty to be enacted by the National Assembly before being applicable in Nigeria. The requirement for domestication has been done away with by this constitutional amendment.

The position of the law is that while ratification makes an international convention's provisions to be legally binding on the member states, domestication makes it possible for the citizens to enforce the provisions in court. The import of the above Section that has done away with the issue of domestication of labour treaties is that once the Conventions have been ratified, Nigerians can now enforce the provisions of all labour related international conventions, treaties and protocols in court without having to wait for the National Assembly to legislate on such issues. Also,

57 CEACR 2008, published in 2009: Handbook for ILO Tripartite Constituents, (n 38) 17.

58 The Constitution of the Federal Republic of Nigeria (Third Alteration Act) 2010, Section 6.

59 See Vienna Convention on the Law of Treaties, 1969. 
the provisions of internal laws cannot be invoked as justification for failing to perform obligations under a treaty. ${ }^{59}$

The provisions of the Constitution of the Federal Republic of Nigeria (Third Alteration) Act, 2010 stated above ${ }^{60}$ is quite novel in the annals of legislative enactments in Nigeria. However, to ensure that the Convention is effectively applied after ratification, the Nigerian government needs to develop co-ordinated and systematic action to protect their rights and guarantee respect for their integrity. ${ }^{61}$ Similarly, it is pertinent to ensure the existence of agencies or other appropriate mechanisms to administer the programmes and ensure the fulfilment of the functions they are to carry out for the benefit of the indigenous peoples. ${ }^{62}$ Equally important is the need to plan, coordinate, execute and evaluate all programmes with the consultation and participation of the people. ${ }^{63}$ Similarly, government must propose legislative and other measures to regulatory authorities concerned with business activities in the Niger Delta and supervise the manner the measures taken are applied in conjunction with the people concerned.

Ratification of the ILO Convention by the Nigerian government could provide normative foundation for a more harmonious and trustbased relationship between the government and stakeholders in the Niger Delta. Campaigns for ratification in themselves provide a platform for advancing indigenous peoples' issues - a process towards ratification can create consensus and shared commitment. Ratification also provides a commitment-based platform for establishing harmonious and cooperative relationships between indigenous peoples and the State. Furthermore, ratification opens the way for ILO supervision and technical assistance, ensuring systematic and long-term follow-up to the commitments undertaken.

Ratifying the ILO Convention could also stimulate foreign investment in the Niger Delta. Donors and development partners view the acceptance of legal obligations by a given State as an indicator of

60 Section 254 (c)(2) states "Notwithstanding anything to the contrary in this constitution, the NIC shall have the jurisdiction and power to deal with any matter connected with or pertaining to the application of any international convention, treaty or protocol of which Nigeria has ratified relating to labour, employment, workplace, industrial relations or matters connected therewith".

61 ILO Convention 169, Article 2(1).

62 ILO Convention 169, Article 33(1).

63 ILO Convention 169, Article 33(2)(a). 
commitment and sustainability. Ratification therefore provides an opportunity for the Nigerian government to deepen investor confidence on its political will to effectively manage the perennial conflicts in the Niger Delta.

Lastly, ratification could provide local communities legal basis to demand transparency, accountability, and greater participation in resource management in the Niger Delta. Generally, states are required to fully implement their international commitments. Ratifying States can be held accountable for non-compliance at the international level. Similarly, ratified treaties are a source of international law that can be invoked in judicial proceedings at the national level. By ratifying the convention, environmental advocates, community leaders and stakeholders in the Niger Delta can better demand for the realization of participatory rights in the Niger Delta.

On the basis of the foregoing, it is pertinent for Nigeria to ratify the ILO Convention 169 so as to provide constitutional basis for the protection and fulfilment of participatory rights in the Niger Delta.

\section{CONCLUSION}

The ILO Convention is an international treaty that becomes binding upon ratification. Ratifying the Convention depicts the willingness of a State to ensure that the rights of her indigenous population are respected, while equally ensuring that socio-economic gaps are closed as exclusion and discrimination are reversed.

For national development to take place, it must be underpinned by a human rights-based approach to development that emphasizes universality, equality, participation and accountability. A culturally sensitive approach based on respect for and inclusion of indigenous people's world-views, perspectives and experiences, as well as their concepts of development must be adopted.

The foregoing discussions have brought to light the benefits derivable from the ILO Convention for indigenous populations, with a focus on the people of Niger Delta. The amendment of Section 254(c) (2) of the Nigerian Constitution now enables labour treaties to be directly enforceable without waiting for the national assembly to domesticate the Convention.

It is important for the Nigerian Government to, as a matter of utmost exigency, ratify the ILO Convention 169 and embrace all it has to offer for the development of the Niger Delta and the advancement of its people. Ratifying and implementing the provisions of the Convention could provide solutions to many of the entrenched challenges that have perennially stifled sustainable development in the Niger Delta. 